\title{
PENGEMBANGAN MEDIA PEMBELAJARAN BERBASIS ADOBE FLASH UNTUK MENINGKATKAN KEMAMPUAN PENALARAN MATEMATIS SISWA
}

\author{
Ricki Yuliardi ${ }^{1}$, Ahmad Fajri Lutfi ${ }^{2}$ \\ ${ }^{1}$ STKIP Muhammadiyah Kuningan \\ rickisyahidan27@upmk.ac.id
}

\begin{abstract}
This research produces a product of interactive math-based learning media flash CS6 to improve students' reasoning in learning mathematics. Methods used are Research and Development with (1) self evaluation, (2) prototyping (expert review, one-to-one, and small group), and (3) field test. Based on research results, then it can be concluded that the developed learning media already valid and effective in improving students' mathematical reasoning abilities. Based on field tests, there are significant differences in the average students before and after using flash, in other words learning media based adobe Flash effectively improve students' reasoning abilities in the concept of geometry.
\end{abstract}

Keywords: Reasearch \& Development Adobe Flash Penalaran Matematis

\section{ABSTRAK}

Penelitian ini menghasilkan produk media pembelajaran matematika berbasis adobe flash CS6 interaktif, untuk meningkatkan penalaran siswa dalam pembelajaran matematika. Metode yang digunakan adalah Penelitian dan Pengembangan dengan (1) evaluasi diri, (2) prototyping (tinjauan ahli, satu-ke-satu, dan kelompok kecil), dan (3) uji lapangan. Berdasarkan hasil penelitian, maka dapat disimpulkan bahwa media pembelajaran yang dikembangkan sudah valid dan efektif dalam meningkatkan kemampuan penalaran matematika siswa. Berdasarkan uji lapangan, terdapat perbedaan signifikan pada rata-rata siswa sebelum dan sesudah menggunakan flash, dengan kata lain media pembelajaran berbasis Adobe Flash efektif meningkatkan kemampuan penalaran siswa dalam konsep geometri.

Kata Kunci: Research \& Development, adobe flash, penalaran matematis

\section{PENDAHULUAN}

Menyadari pentingnya matematika, maka pembelajaran matematika harus menjadi kebutuhan dan aktivitas yang menyenangkan. Namun dunia pendidikan matematika dihadapkan pada masalah rendahnya hasil belajar matematika siswa di setiap jenjang pendidikan. Salah satu penyebab rendahnya hasil belajar matematika siswa karena banyak siswa menganggap matematika sulit dipelajari dan karakteristik matematika yang abstrak sehingga siswa menganggap matematika adalah sesuatu yang menakutkan. Nurdalillah (2013) mengatakan bahwa dari berbagai bidang studi yang diajarkan di sekolah, matematika adalah bidang studi yang dianggap paling sulit oleh siswa, baik ketidakmampuan belajar maupun bagi siswa dengan hambatan belajar.
Salah satu keterampilan matematika yang diperlukan dalam pembelajaran adalah kemampuan penalaran. Berdasarkan peraturan Menteri Pendidikan Nasional (Permendiknas) (2013) tentang Standar Konten, menyatakan bahwa salah satu tujuan pembelajaran matematika di sekolah adalah bahwa siswa harus memiliki kemampuan penalaran. Dalam domain kognitif kemampuan penalaran, termasuk kemampuan untuk menganalisis, menyamaratakan, mengintegrasikan, memberikan pembenaran, dan memecahkan masalah non-rutin, (Mullis, 2009). Ini berarti bahwa penalaran matematis adalah dasar untuk memperoleh atau membangun pengetahuan matematika. Permana \& Utari (2007) menyatakan bahwa penalaran adalah 
keterampilan matematika dasar yang harus dikuasai siswa, karena dengan penalaran dapat membantu siswa dalam memecahkan masalah matematika yang dihadapi baik di sekolah maupun di kehidupan sehari-hari. Dari pengertian ini dapat disimpulkan bahwa seorang siswa dapat menguasai matematika secara keseluruhan jika siswa memiliki kemampuan dalam penalaran.

Dengan demikian guru di sekolah dasar dan menengah harus mengembangkan keterampilan penalaran siswa dalam pembelajaran matematika. Seorang guru matematika harus mengembangkan kemampuan penalaran siswa dalam proses pembelajaran matematika, tetapi fakta di lapangan berdasarkan hasil penelitian tentang kemampuan penalaran siswa masih kurang, seperti yang disarankan oleh Riyanto (2011), yang menemukan kualitas siswa memuaskan, yaitu masing-masing sekitar 49\% dan 50\% dari skor ideal. Selain itu menurut Puspendik (2012), berdasarkan hasil penelitian TIMSS 2011 (Lembaga Survey Matematika dan Ilmu Pengetahuan Internasional) melakukan survey pada siswa SMP, menyatakan bahwa rata-rata pencapaian keterampilan penalaran siswa pada umumnya berada pada tingkat rendah. Prestasi rata-rata peserta Indonesia di TIMSS 2011 telah menurun dari pencapaian rata-rata pada tahun 2007. Kemampuan rata-rata siswa dari Indonesia di masing-masing domain ini masih jauh di bawah negara tetangga Malaysia, Thailand dan Singapura. Persentase rata-rata terendah yang dicapai oleh peserta Indonesia adalah pada domain kognitif pada tingkat penalaran $17 \%$. Melihat kondisi tersebut, maka dibutuhkan cara untuk mengatasi masalah tersebut. Salah satu cara yang dianggap cocok untuk mengatasinya adalah dengan menggunakan media pembelajaran berbasis Adobe Flash CS6. Adobe Flash CS6 media pengembangan materi materi bangunan untuk meningkatkan kemampuan penalaran matematika siswa SMP adalah salah satu bentuk nyata pembelajaran berbasis IT menggunakan Adobe Flash CS6 media. Media ini memfasilitasi guru untuk menerapkan pembelajaran yang interaktif dan bermakna sehingga siswa dapat meningkatkan kemampuan mereka untuk menarik kesimpulan dari masalah matematika yang disajikan.

\section{METODE PENELITIAN}

\section{A. Metode Penelitian Research and Development.}

Proses penelitian ini menggunakan metode Research and Development (R \& D). Menurut Zulkardi (2002) tahapan pengembangan masalah terdiri dari dua tahap utama: tahap pendahuluan (tahap persiapan) dan tahap evaluasi formatif. Pada tahap evaluasi formatif langkahlangkah yang diambil mengikuti langkahlangkah yang diusulkan oleh Tessmer (1993) yang meliputi (1) evaluasi diri, (2) prototyping (tinjauan ahli, satu-ke-satu, dan kelompok kecil), dan (3) lapangan uji. Pada tahap awal, peneliti menganalisis kendala yang dialami guru dalam pembelajaran, analisis kurikulum SMP, dan sarana dan prasarana yang tersedia. Dari hasil analisis awal ditemukan masalah: keterbatasan media pembelajaran yang digunakan oleh guru dalam menjelaskan konsep geometri bangunan, keterbatasan sarana dan prasarana dan juga masih kurangnya inovasi guru dalam pembelajaran. Selanjutnya, perancangan media pembelajaran matematika berbasis Adobe CS6 yang mencakup materi pembelajaran, aktivitas interaktif dan masalah latihan. Setelah memproduksi adobe-based adobe flash design CS 6 dilanjutkan di tahap evaluasi formatif.

\section{B. Fase Evaluasi Formatif}

Pada tahap ini, penilaian oleh peneliti sendiri, hasil dari perancangan pembelajaran matematika berbasis adobe flash media CS 6 untuk mendukung pembelajaran matematika siswa SMP kelas VII Kurikulum 2013. Dari tahap ini akan diperoleh prototipe I. 


\section{Fase Validasi Ahli}

Pada tahap ini desain konten material dan media pembelajaran yang dibuat oleh peneliti divalidasi oleh para ahli dan guru matematika sebagai pemangku kepentingan. Ada ahli yang terdiri dari dosen matematika dan guru matematika yang memvalidasi media pembelajaran dalam hal konten. Adapun validasi ahli media divalidasi oleh dua dosen Teknologi dan informasi. Produk yang dirancang dan diatur akan dilihat, dinilai, dan dievaluasi. Uji validitas yang dilakukan adalah uji validitas isi, uji validitas konstruk, dan uji validitas bahasa. Saran dari validator digunakan untuk merevisi desain dan komposisi pertanyaan yang dibuat peneliti. Umpan balik dan saran yang valid tentang desain dan komposisi pertanyaan yang telah dibuat ditulis pada lembar validasi sebagai bahan untuk merevisi dan menyatakan bahwa pertanyaan yang dikembangkan adalah valid. Dari tahap ini dan juga setelah melalui Focus Group Discussion (FGD).

Secara paralel (bersamaan), juga dilakukan tahap satu ke satu. Pada tahap ini prototipe saya diuji ke 5 siswa sebagai penguji yang diminta untuk mempelajari konsep geometri dengan menggunakan media pembelajaran berdasarkan program adobe flash CS6 yang sedang dikembangkan dan juga diminta untuk memberikan komentar / tanggapan atas masalah mereka. Hasil atau temuan yang diperoleh pada tahap tinjauan ahli dan satu-ke-satu dipertimbangkan dalam merevisi prototipe I. Setelah prototipe yang direvisi saya akan menghasilkan prototipe II. Dari proses validasi dan focus group discussion (FGD), prototipe saya direvisi dan diperoleh dengan prototipe II. Dokumen yang digunakan dalam langkah ini adalah berupa lembar penilaian, saran dan notulen FGD. Hasil penilaian umum dari lima validator diberikan pada Tabel 1. Dari hasil penilaian di atas tampak bahwa dalam hal materi sangat baik, hampir tidak ada masalah, dalam hal konstruk ada beberapa hal yang perlu ditingkatkan, sedangkan dari segi bahasa agak banyak yang harus diperbaiki.

Tabel 1. Hasil Penilaian

\begin{tabular}{ccc}
\hline Jenis Validasi & Skor & Kategori \\
\hline $\begin{array}{c}\text { Isi Keabsahan } \\
\text { Konstruk }\end{array}$ & 4,6 & $\begin{array}{c}\text { sangat } \\
\text { baik }\end{array}$ \\
$\begin{array}{c}\text { Validitas } \\
\text { Bahasa Validitas }\end{array}$ & 3,8 & $\begin{array}{c}\text { Baik } \\
\text { sangat } \\
\text { baik }\end{array}$ \\
\hline
\end{tabular}

Dari hasil penilaian di atas nampak dari sisi materi sangat baik, hampir tidak ada masalah, dalam hal membangun ada beberapa hal yang perlu ditingkatkan, sedangkan dalam hal bahasa agak banyak perlu diperbaiki.

Prototipe II selanjutnya diuji dalam tahap grup kecil. Pada tahap ini, 20 siswa dari SMP 2 Luragung diminta untuk mempelajari konsep geometri dengan menggunakan media pembelajaran berdasarkan program adobe flash CS6 dan menyelesaikan masalah dalam prototipe II dan juga mengomentari masalah yang telah dilakukan. Komentar dan temuan dari tahap kelompok kecil ini dipertimbangkan dalam merevisi Prototipe II. Hasil revisi prototipe II disebut prototipe III atau disebut juga tahap uji lapangan, peneliti melakukan uji coba untuk melihat tingkat efektivitas media pembelajaran dalam meningkatkan pemahaman matematika siswa. Hasilnya dianalisis dan didiskusikan sehingga menghasilkan saran dan menghasilkan prototipe akhir. Prototipe akhir ini diuji dengan subjek penelitian sebanyak 40 siswa kelas VIII dari dua sekolah yaitu SMP 2 Luragung dan SMP 1 Maleber bahkan semester 2017 / 2018. Hasil tes lapangan dihitung skor masingmasing siswa dan digunakan sebagai dasar penilaian kemampuan penalaran matematis 


\section{HASIL DAN PEMBAHASAN}

\section{A. Hasil}

Dari hasil FGD dan revisi prototipe I di atas, ada beberapa hal yang bisa dibahas. Beberapa hal yang memandu persiapan pertanyaan yang bagus menurut dosen dan guru matematika, disajikan dalam tabel di bawah :

Tabel 2. Saran dan Perbaikan Media

\begin{tabular}{|c|c|c|}
\hline No & Saran & Perbaikan Media \\
\hline 1 & $\begin{array}{l}\text { Diagram alur harus dibuat yang akan } \\
\text { menggambarkan alur program }\end{array}$ & $\begin{array}{l}\text { Saran diterima, program yang } \\
\text { dikembangkan berdasarkan diagram yang } \\
\text { telah dibuat }\end{array}$ \\
\hline 2 & $\begin{array}{l}\text { Harus di media berbasis flash, berisi } \\
\text { kompetensi dasar yang harus dikuasai } \\
\text { oleh siswa }\end{array}$ & $\begin{array}{l}\text { saran yang dapat diterima, kompetensi } \\
\text { dasar dan indikator pembelajaran } \\
\text { ditambahkan ke media }\end{array}$ \\
\hline 3 & $\begin{array}{l}\text { Kami merekomendasikan } \\
\text { menambahkan ilustrasi untuk masalah } \\
\text { yang membutuhkan visualisasi gambar }\end{array}$ & $\begin{array}{l}\text { Saran diterima, program akan dilengkapi } \\
\text { dengan gambar untuk memfasilitasi } \\
\text { visualisasi siswa }\end{array}$ \\
\hline 4 & $\begin{array}{l}\text { Peningkatan kualitas soal latihan yang } \\
\text { ditemukan dalam program }\end{array}$ & $\begin{array}{l}\text { Saran yang diterima, kualitas soal latihan } \\
\text { akan ditingkatkan }\end{array}$ \\
\hline 5 & Kesalahan ketik masih harus diperbaiki & Saran diterima, kesalahan dikoreksi \\
\hline 6 & $\begin{array}{l}\text { Penggunaan animasi yang dapat } \\
\text { meningkatkan penalaran matematika }\end{array}$ & $\begin{array}{l}\text { Saran diterima, animasi dibuat untuk } \\
\text { membantu kemampuan penalaran } \\
\text { matematis siswa }\end{array}$ \\
\hline 7 & Equalization template menu diprogram & Saran diterima dan dianggap \\
\hline 8 & $\begin{array}{l}\text { Umpan balik jawaban siswa dalam } \\
\text { program yang }\end{array}$ & $\begin{array}{l}\text { Saran diterima, umpan balik akan dibuat } \\
\text { dengan jawaban kunci untuk latihan siswa }\end{array}$ \\
\hline 9 & $\begin{array}{l}\text { Kedepan semoga program ini dapat } \\
\text { digunakan dalam perangkat android }\end{array}$ & Saran diterima dan dianggap \\
\hline 10 & $\begin{array}{l}\text { program adobe flash ini dapat menjadi } \\
\text { alternatif media pembelajaran yang } \\
\text { direkomendasikan oleh kementerian } \\
\text { pendidikan }\end{array}$ & saran diterima dan dipertimbangkan \\
\hline
\end{tabular}

Setelah direvisi, berikut ini ditampilkan media pembelajaran berbasis Adobe Flash yang dikembangkan untuk membantu siswa penalaran matematis dalam konsep membangun ruang samping yang datar:

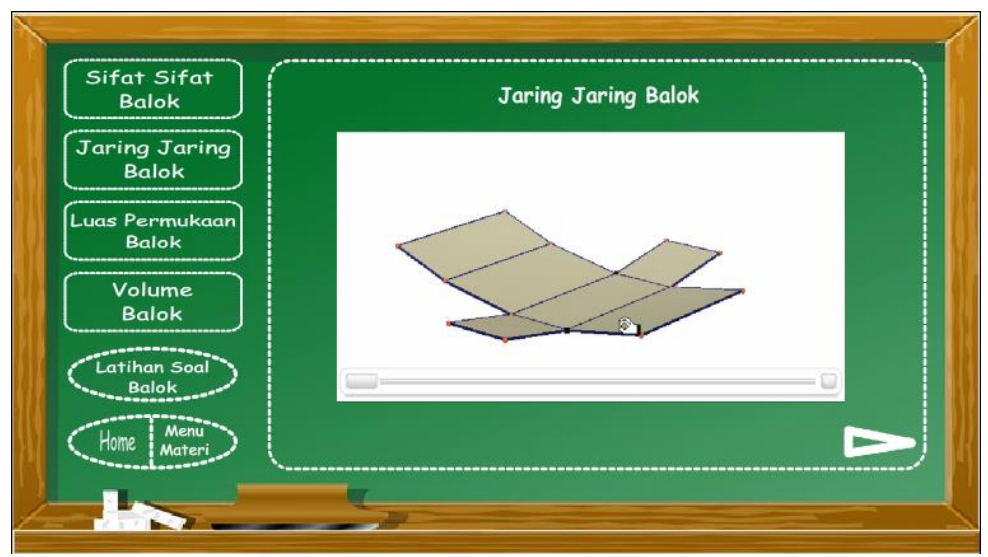

Gambar 1: Tampilan animasi dari jaring bangunan balok 


\section{B. Pembahasan}

Berdasarkan hasil dari bidang uji diketahui Hasil tes tentang penalaran matematis pada 52 siswa, diketahui: (1) berdasarkan kemampuan penalaran yang termasuk dalam kategori sangat baik berjumlah 9 siswa (17,31\%), kategori tinggi berjumlah 26 siswa $(50,00 \%)$, kategori sedang 12 siswa $(23,08 \%)$ dan kategori rendah sebanyak 5 siswa $(9,62 \%)$;

Tabel 3. Rata-rata Tes Distribusi Frekuensi Siswa pada Tes Lapangan

\begin{tabular}{cccc}
\hline $\begin{array}{c}\text { Nilai } \\
\text { Sisw } \\
\text { a }\end{array}$ & $\begin{array}{c}\text { Tingkat } \\
\text { Penalaran } \\
\text { Matematik } \\
\text { a }\end{array}$ & $\begin{array}{c}\text { Frekuen } \\
\text { si }\end{array}$ & $\begin{array}{c}\text { Rata } \\
- \text { rata } \\
\mathbf{( \% )}\end{array}$ \\
$84-$ & Sangat & & \\
100 & Tinggi & 9 & 17,31 \\
$65-84$ & Tinggi & 26 & 50,00 \\
$45-64$ & Sedang & 12 & 23,08 \\
$25-44$ & Rendah & 5 & 9,62 \\
$0-24$ & Sangat & 0 & 0,00 \\
& Rendah & & $\mathbf{1 0 0}$ \\
\hline & Total & $\mathbf{5 2}$ & $\mathbf{1}$ \\
\hline
\end{tabular}

\section{Uji keefektifan model}

Salah satu bagian penting yang tidak kalah penting dari tahap penelitian dalam $\mathrm{R} \& \mathrm{D}$ adalah menguji keefektifan dan uji efisiensi. Uji efektivitas digunakan untuk membuktikan apakah model tersebut mampu mencapai tujuan yang ditetapkan atau tidak. Sebelum uji efektivitas, ada beberapa uji statistik yang harus dilakukan oleh peneliti seperti: uji normalitas dan uji homogenitas. Uji normalitas berfungsi untuk mengetahui apakah distribusi data responden terdistribusi normal atau tidak. Uji normalitas akan berpengaruh pada penggunaan alat uji statistik dalam uji efektivitas model, apakah akan menggunakan statistik parametrik atau non parametrik. Dengan menggunakan SPSS, uji normalitas dapat menggunakan rumus "Kolmogorov Smirnov". Data dikatakan normal jika nilai signifikansi menunjukkan $(p, 0,05)$ yang berarti data tidak berbeda dari distribusi kurva normal data.
Tabel 4.Tes Normalitas

\begin{tabular}{|c|c|c|c|c|c|c|}
\hline & \multicolumn{3}{|c|}{$\begin{array}{l}\text { Kolmogorov- } \\
\text { Smirnova }\end{array}$} & \multicolumn{3}{|c|}{ Shapiro-Wilk } \\
\hline & $\begin{array}{l}\text { Stati } \\
\text { stik }\end{array}$ & $\begin{array}{l}\text { D } \\
f\end{array}$ & $\begin{array}{l}\text { S } \\
\text { i } \\
\text { g }\end{array}$ & $\begin{array}{c}\text { Stat } \\
\text { isti } \\
\mathrm{k}\end{array}$ & $\begin{array}{l}\mathrm{d} \\
\mathrm{f}\end{array}$ & $\begin{array}{l}\text { S } \\
\text { i } \\
\text { g }\end{array}$ \\
\hline Sk & & & & & & \\
\hline $\begin{array}{l}\text { or } \\
\text { Pre } \\
\text { tes }\end{array}$ & $\begin{array}{r}13 \\
3\end{array}$ & 52 & $\begin{array}{l}0 \\
2\end{array}$ & 968 & $\begin{array}{l}5 \\
2\end{array}$ & 1 \\
\hline $\begin{array}{l}\mathrm{t} \\
\mathrm{Sk}\end{array}$ & & & 2 & & & \\
\hline $\begin{array}{l}\text { or } \\
\text { Pos } \\
\text { tes } \\
t\end{array}$ & $\begin{array}{r}15 \\
3\end{array}$ & 52 & $\begin{array}{l}0 \\
0 \\
4\end{array}$ & 946 & $\begin{array}{l}5 \\
2\end{array}$ & $\begin{array}{l}0 \\
2 \\
0\end{array}$ \\
\hline
\end{tabular}

a. Korelasi Signifikansi Lilliefors

Karena nilai signifikansi skor pretest dan postest kurang dari 0,05 ( $p<0,05$ ), maka kesimpulan dari data memiliki distribusi abnormal, sehingga akan diuji hipotesis non parametris. Statistik nonparametrik untuk uji keefektifan model menggunakan SPSS adalah melalui rumus Wilcoxon Paired Samples Test.

Hipotesis penelitian:

H0: Tidak ada perbedaan antara nilai rata-rata pretest dan posttest

H1: Ada perbedaan rata-rata antara skor pretest dan posttest

Tabel 5. Wilcoxon Test Statisticsa

\begin{tabular}{ll}
\hline & $\begin{array}{l}\text { Skor Postest - } \\
\text { Skor Pretest }\end{array}$ \\
\hline $\mathrm{Z}$ & $-6,284^{\mathrm{b}}$ \\
$\begin{array}{l}\text { Asymp. Sig. (2- } \\
\text { tailed) }\end{array}$ &, 000 \\
\hline $\begin{array}{l}\text { a. Wilcoxon Signed Ranks Test } \\
\text { b. Berdasarkan peringkat negatif. }\end{array}$
\end{tabular}

Nilai Z untuk uji non parametrik adalah 6,284 dengan signifikansi $\mathrm{p}=0,000(\mathrm{p}$ $<0,05)$ yang berarti $\mathrm{H}_{0}$ ditolak dan $\mathrm{H}_{1}$ diterima, sehingga disimpulkan bahwa ada perbedaan rata-rata yang signifikan antara skor pretest dan skor posttest di grup kontrol.

\section{SIMPULAN DAN SARAN}

A. Kesimpulan 
Penelitian ini menghasilkan model pembelajaran matematika berbasis adobe flash untuk siswa SMP yang telah dikembangkan berdasarkan langkahlangkah yang diusulkan oleh Tessmer (1998). Berdasarkan uraian tahap persiapan dan uji validitas isi para ahli menunjukkan bahwa masalah yang berkembang sudah sesuai dengan indikator kompetensi dasar Kementerian Pendidikan. Berdasarkan hasil analisis jawaban siswa selama tes lapangan, dari 5 deskripsi, kategori sangat baik adalah 9 siswa (17,31\%), kategori tinggi adalah 26 siswa (50,00\%), kategori sedang 12 siswa $(23,08 \%)$ dan kategori rendah sebanyak 5 siswa (9,62\%); sehingga dapat disimpulkan sebagian besar siswa memiliki kemampuan penalaran matematis yang baik. Ini bisa dilihat dari jawaban dan alasan yang diberikan pada lembar jawaban. Indikator penalaran seperti menganalisis masalah matematika, membuat generalisasi masalah dan memecahkan masalah nonrutin, memberikan penjelasan dengan menggunakan pernyataan matematis, mengintegrasikan fakta dan prosedur matematika untuk mendapatkan solusi akhir. Namun demikian, ada beberapa siswa yang mampu memahami masalah tetapi masih merasa sulit untuk memberikan penjelasan menggunakan model atau pernyataan matematika dan masih merasa sulit untuk membuat pernyataan yang mendukung / menolak argumen. Hal ini dapat dilihat dari kesulitan siswa dalam memecahkan pengaturan masalah dengan menggunakan matematika dan menerapkan fakta-fakta matematika, konsep, dan prosedur dalam konteks yang kompleks dan asing. Secara keseluruhan berdasarkan hasil analisis jawaban siswa disimpulkan bahwa masalah yang telah dikembangkan dapat dipahami dengan baik oleh siswa. Pemanfaatan teknologi secara umum terbukti meningkatkan keterampilan matematika siswa. Hal ini sejalan dengan Yuliardi (2017), yang menyatakan pembelajaran matematika dengan bantuan perangkat lunak dapat meningkatkan keterampilan matematika siswa. Berdasarkan uraian yang telah dijelaskan sebelumnya dapat disimpulkan bahwa model pembelajaran berbasis flash adobe yang telah dikembangkan memiliki efek potensial terhadap kemampuan penalaran matematis siswa SMP.

\section{B. Saran}

Berdasarkan hasil penelitian, maka dapat disimpulkan bahwa media pembelajaran yang dikembangkan sudah memenuhi kriteria valid dan efektif dalam meningkatkan kemampuan penalaran matematika siswa. Valid secara teoritis dapat menilai dari hasil penilaian validator, yang semuanya validator menyatakan bahwa hal tersebut telah baik berdasarkan konten, konstruksi dan bahasa. Berdasarkan hasil tes lapangan, ada perbedaan yang signifikan dalam rata-rata siswa sebelum dan sesudah menggunakan media pembelajaran berbasis flash, dengan kata lain adobe flash-based learning media secara efektif meningkatkan kemampuan penalaran siswa dalam konsep geometri. Berdasarkan hasil penelitian dan kesimpulan, disarankan untuk peneliti lain untuk mengembangkan media pembelajaran berbasis adobe flash sehingga dapat membantu guru untuk memperkaya variasi pemberian konsep matematika dalam proses pembelajaran yang inovatif.

\section{DAFTAR PUSTAKA}

Kementerian Pendidikan dan Kebudayaan (Kemendikbud). (2013). Lampiran Peraturan Menteri Pendidikan dan Kebudayaan Republik Indonesia Nomor Tahun 2013 Tentang Silabus Sekolah Menengah PertamaMadrasah Tsanawiyah pada Kelas VII. Badan Penelitian dan Pengembangan Kurikulum dan Perbukuan Tahun 2013.

Mullis, I., dkk. (2009). Kerangka kerja Assesment TIMSS 2011. Chesnut Hills: Boston College. 
Nurdalillah., Dkk. (2013). Perbedaan Penalaran Matematika Dan Pemecahan Masalah Pada Pembelajaran Masalah Dan Pembelajaran Konvensional di SMA Negeri 1 Kualuh Selatan. Jurnal Pendidikan Matematika PARADIKMA Vol.6 No.2. [Online] Diperoleh 20 Mei 2017, dari http://digilib.unimed.ac.id pdf.

Permana, Y \& Utari, S. (2007). Mengembangkan kemampuan penalaran dan koneksi matematik siswa sma melalui pembelajaran berbasis masalah. Jurnal Educationist, Vol. 1, No. 2, Juli 2007, hlm. 116-123.

Puspendik. (2012). Laporan Hasil TIMSS 2011 Matematika. Jakarta: Puspendik, Balitbang Depdiknas.

Riyanto, B. (2011). Meningkatkan Kemampuan Penalaran Dan Prestasi Matematika Dengan Pendekatan Kontruktivisme Pada Siswa Sekolah Menengah Atas. Jurnal Pendidikan Matematika Vol.5 No.2 Juli 2011 [online] Diperoleh 27 Mei 2017, dari http://download.portalgaruda.org/arti cle.php.pd.

Tessmer, Martin. (1993). Merencanakan dan Melakukan Evaluasi Formatif. London. Halaman Kogan.

Tessmer, Martin. (1998). Merencanakan dan melakukan evaluasi formatif: meningkatkan kualitas pendidikan dan pelatihan. London: Kogan Page.

Yuliardi, R. \& Nurjanah. (2017). Belajar Matematika Membantu Geogebra menggunakan Kelas Berorientasi Teknologi (TAC) untuk Meningkatkan Keterampilan Komunikasi Siswa Sekolah Menengah Kejuruan. Jurnal Fisika: Seri Konferensi.

Zulkardi, Z. (2002). Mengembangkan lingkungan belajar pada pendidikan matematika realistis untuk guruguru bahasa Indonesia. Disertasi doktoral. Enschede: Universitas Twente, Enschede. Belanda. (On line). Diakses 20 Oktober 2017, dari: http: //doc.utwente.nl/58718/1/ thesis_Zulkardi.pdf. 
